\section{Aborto: análise retrospectiva de uma prática atemporal}

Fontenele, A

Universidade de Brasília (UnB); Programa de PósGraduação em Enfermagem (PPGEnF) e-mail: alelimafontenele@gmail.com

\section{Guilhem, D}

Universidade de Brasília (UnB); Programa de PósGraduação em Enfermagem (PPGEnF); Programa de PósGraduação em Ciências da Saúde (PPGCS).

PALAVRAS-CHAVE: Aborto; Bioética; Moralidade

O aborto abarca um campo de tensões circundado por controvérsias morais. Sua legalização em diversos países não foi capaz de diminuir os conflitos que emergem da discussão sobre o tema, tornando-se necessário ampliar a análise em distintas esferas, como a política, a econômica, a saúde e a ética. Constitui-se como um dos poucos assuntos capazes de provocar profundas divisões sociais. A compreensão sobre as questões envolvidas e os desdobramentos morais decorrentes dessa prática requerem a retomada de um breve histórico, o que possibilita a análise da forma como o tema vem sendo tratado ao longo da história da humanidade. Este trabalho teve como objetivo realizar uma análise histórica e jurídica subjacentes ao aborto e as possíveis consequências para as diferentes moralidades que emergem da vida em sociedade. Foi realizada uma revisão da literatura a partir de livros e artigos científicos, o que permitiu analisar do ponto de vista bioético os distintos posicionamentos existentes no mundo e consequentemente as posições morais frente aos novos paradigmas propostos na atualidade. Foi possível resgatar e vincular: momentos históricos, localidades, crenças e significados atribuídos a este fenômeno. Observouse que conhecer a historicidade do aborto permitiu verificar continuidades e descontinuidades no debate, obrigando-nos a ampliar horizontes e repensar as diferentes perspectivas relacionadas à sua problemática.

AGRADECIMENTOS: O presente trabalho foi realizado com apoio da Coordenação de Aperfeiçoamento de Pessoal de Nível Superior - Brasil (CAPES) - Código de Financiamento 001 - através da concessão de bolsa de mestrado; e com o apoio do Conselho Nacional de Desenvolvimento Científico e Tecnológico (CNPq) pela concessão de bolsa de Produtividade em Pesquisa 1-D, que foram fundamentais para a realização desse estudo.

\section{REFERÊNCIAS}

[1] BALBINOT, RAAA. O Aborto: perspectivas e abordagens diferenciadas. Revista Sequência, n. ${ }^{\circ}$ 46, p. 93119 , jul. de 2003.
[2] MORI, M. A Moralidade do Aborto. Brasília, Editora: UnB. 1997

[3] REBOUÇAS, MSS, Dutra EMS. Não nascer: algumas reflexões fenomenológico-existenciais sobre a história do aborto. Psicologia em Estudo, Maringá, v. 16, n. 3, p. 419428, jul./set. 2011.

[4] Center For Reproductive Rights. Religious Voices World Wide Support Choice [internet]. Sept, 2017. Disponível em: https://www.reproductiverights.org/sites/crr.civicactions.net/ files/documents/pub_bp_tk_religious.pdf. Acesso em: 09 de maio, 2018.

[5] Center For Reproductive Rights. The World's Abortion Laws 2018 - Map [internet]. Disponível em: < http://worldabortionlaws.com/>. Acesso em: 03 de abril, 2018 